\title{
Cerium isotope constraints on Hawaiian mantle sources
}

\author{
P. BÉGUELIN ${ }^{1}$, M. BizIMis ${ }^{2}$, A. STRACKE ${ }^{1}$, M. WILliG $^{1}$ \\ ${ }^{1}$ University of Münster, 48149 Münster, Germany \\ (*correspondence: beguelin@uni-muenster.de) \\ ${ }^{2}$ SEOE, Univ. of South Carolina, Columbia, SC 29208, USA
}

Along with the widely-used $\mathrm{Nd}$ and $\mathrm{Hf}$ isotope ratios, $\mathrm{Ce}$ isotopes are tracers of the time-integrated rare-earth element signature of mantle sources. The sampling of depleted mantle source components generally results in overlapping trends in $\mathrm{Nd}-\mathrm{Hf}$ isotope space ${ }^{1}$. However, the variable fractionation of $\mathrm{La} / \mathrm{Ce}$ from $\mathrm{Sm} / \mathrm{Nd}$ and $\mathrm{Lu} / \mathrm{Hf}$ during mantle melting makes the presence of distinct time-integrated trace-element depleted source components in lavas appearent in $\mathrm{Ce}-\mathrm{Nd}$ and $\mathrm{Ce}-\mathrm{Hf}$ isotope space. Hence, combined Ce-Nd-Hf isotope studies are particularly well-suited for investigating the influence of variably depleted source components in Earth's mantle ${ }^{2,3}$.

Here we present $\mathrm{Ce}$ isotope data for a set of well documented Hawaiian lavas from $\mathrm{O}$ ‘ahu, Kaua'i and $\mathrm{Ni}^{\prime}$ ihau islands with the aim to investigate the importance of varaibly depleted source components on the isotopic variability in these Hawaiian lavas. The investigated lavas form stacked island-specific arrays in Ce-Nd and Ce-Hf isotope space. We show that lavas from $\mathrm{O}$ 'ahu (Makapu'u series) cannot fit on a mixing cruve with Kaua'i and $\mathrm{Ni}^{\prime}$ 'ihau lavas, requiring the presence of multiple isotopically depleted endmembers with varying ${ }^{143} \mathrm{Nd} /{ }^{144} \mathrm{Nd}$ and ${ }^{176} \mathrm{Hf} /{ }^{177} \mathrm{Hf}$ ratios for a given ${ }^{138} \mathrm{Ce} /{ }^{136} \mathrm{Ce}$.

A recycled mafic component in the upwelling plume with parent/daughter ratios akin to depleted MORB probably dominates the $\mathrm{Ce}-\mathrm{Nd}-\mathrm{Hf}$ istotope systematics of Makapu'u lavas. Kaua' $\mathrm{i}$ and $\mathrm{Ni}$ 'ihau lavas from the post-erosional rejuvenated volcanic stage further require the existence of two distinct isotopically depleted sources components.

We show that when considered at the scale of a single hotspot, the $\mathrm{Ce}-\mathrm{Nd}$ and $\mathrm{Ce}-\mathrm{Hf}$ isotope systematics of mantlederived lavas reveals multiple island-specific arrays. Explaining these arrays require the presence of several isotopically distinct depleted components in the upwelling plume, which are indistinct in $\mathrm{Nd}-\mathrm{Hf}$ isotope space alone. Ce isotopes are thus a promising tracer of depleted mantle sources.

[1] Salters et al. (2011) $G^{3}, 12(8)$.

[2] Israel et al. (2020) EPSL, 530, 115941.

[3] Willig et al. (2020) GCA, 272, 36-53. 